SHORT REPORT

\title{
Prevalence of sensitisation to cellulase and xylanase in bakery workers
}

\author{
J Elms, D Fishwick, J Walker, R Rawbone, P Jeffrey, P Griffin, M Gibson, A D Curran
}

Occup Environ Med 2003;60:802-804

\begin{abstract}
Aims: To assess the prevalence of sensitisation to a range of exogenous fungal enzymes used in bakeries, and determine the relation between sensitisation and work related symptoms.

Methods: Serum samples ( $\mathrm{n}=135$ ) from a previous cross sectional study investigating the prevalence of respiratory symptoms and sensitisation to dust components, were reanalysed for specific lgE to the mixed enzymes cellulase, hemicellulase, and xylanase.

Results: Eight (6\%) of sera tested had detectable specific lgE to mixed enzymes (excluding fungal $\alpha$-amylase) and 16 (12\%) to fungal $\alpha$-amylase. A significant increase $(p=0.03$ ) in nasal symptoms was found in those workers sensitised to enzymes (including $\alpha$-amylase and the mixed enzymes, but with or without sensitisation to wheat flour) when compared to those sensitised to wheat flour alone. Both groups had significantly greater levels of nasal symptoms in comparison to those with no evidence of sensitisation.

Conclusions: The association between specific $\lg E$ to mixed enzymes, and an increased prevalence of nasal symptoms in individuals sensitised to enzymes, highlights the importance of measuring sensitisation to the full range of exogenous enzymes used in the baking industry, as well as to wheat flour.
\end{abstract}

$\mathrm{E}$ nzymes are widely used in a variety of industries, to effect chemical changes on a range of substrates. The baking industry began adding exogenous enzymes in the 1970s, and this use has increased over the past 30 years. Many of these enzymes are Aspergillus derived and include $\alpha$ amylase, cellulase, and hemicellulase (especially xylanase), all of which are added to flour to improve dough quality and shelf life of the product.

Although much work has focused on fungal $\alpha$-amylase, ${ }^{1-2}$ there are a few reports, which highlight the potential of other commonly added enzymes to induce respiratory health effects in susceptible individuals. ${ }^{3-6}$ Quirce et al investigated five bakers with work related respiratory symptoms. They measured specific immunoglobulin E (IgE) to both cellulase and $\alpha$-amylase in four of the workers, and specific IgE antibodies to $\alpha$-amylase only, in one of the workers. No cross reactivity between the two enzymes was shown. Additionally Baur and colleagues ${ }^{5}$ showed sensitisation to hemicellulase in symptomatic bakers and in a case report, reported the presence of specific IgE antibodies to xylanase. ${ }^{6}$

We have previously described ${ }^{7}$ the association between work related respiratory symptoms in bakers and the presence of specific IgE to wheat flour and fungal $\alpha$-amylase. This present paper reports the subsequent analysis of serum with respect to other added enzymes, and examines how these relate to respiratory and nasal symptoms.

\section{METHODS}

As previously reported, ${ }^{7}$ a cross sectional study was carried out in 18 small bakeries in Scotland. Two hundred and twenty four workers participated, and supplied 205 serum samples. This paper reports the results of a subanalysis of 135 sera, selected as a sample of convenience, representing those workers with enough serum available for further analysis.

Radioallergosorbent (RAST) analysis was performed according to Ceska and colleagues, ${ }^{8}$ using a mixed enzyme disc prepared by conjugating an equal amount of Aspergillus niger derived cellulase, hemicellulase (Sigma, Dorset, UK), and xylanase (Megazyme, Wicklow, Ireland) to cyanogen bromide activated discs. A RAST score of 2 or more was considered positive. For subsequent analysis, workers were separated into three discrete groups, according to their pattern of specific IgE response. These were defined as follows:

- Not sensitised-RAST negative to wheat flour, fungal $\alpha$ amylase, and mixed enzyme.

- Wheat flour-RAST positive to wheat flour allergens, but negative to fungal $\alpha$-amylase and mixed enzyme.

- Enzyme-RAST positive to either fungal $\alpha$-amylase or the mixed enzymes (with or without specific IgE to wheat flour).

The data from the original standard respiratory questionnaire were used to define four diagnostic groups: any respiratory symptom; any work related respiratory symptom; any nasal symptom; and any work related nasal symptom. Work related symptoms were defined as either rest day improvement or improvement on holidays; nasal symptoms were defined as nasal itching, running, or blockage and sneezing.

All analyses were performed by cross tabulation in SPSS (Statistical Package for Social Scientists, v 10, SPSS Inc., Chicago, USA) with a Mantel-Haenszel common odds ratio estimate. A $\chi^{2}$ test was used to compare proportions. Statistical significance is assumed at the $5 \%$ level.

\section{RESULTS}

The 135 workers undergoing further analysis did not differ significantly in age $(\mathrm{p}=0.817)$, smoking status $(p=0.249)$, or exposure group $(p=0.368)$, from those 70 workers whose serum was not available.

Of those samples reanalysed, $16(12 \%)$ were found to have specific IgE to fungal $\alpha$-amylase, $25(19 \%)$ to wheat, and eight $(6 \%)$ to the mixed enzyme bakery disc. It is of note that of the 18 individuals sensitised to enzymes, 12 were sensitised to wheat flour. Of those individuals who had specific IgE to the mixed enzymes, two individuals were negative for fungal $\alpha$-amylase disc. Only one of these individuals was positive for wheat flour, and although both of these individuals had nasal symptoms, only the wheat positive individual reported that they were work related. There were sufficient sera to screen seven of the eight mixed 
Main messages

- When assessing work related respiratory symptoms in the baking industry, it is useful to measure sensitisation to both endogenous wheat flour and the full range of exogenous enzymes used in the baking industry including cellulase, hemicellulase, and xylanase.

- There is an apparent increased prevalence of nasal symptoms in those sensitised to enzymes used in the baking industry.

enzyme positive workers to individual enzymes. Of these, four $(57 \%)$ had specific IgE to xylanase, six $(86 \%)$ to hemicellulase, and six $(86 \%)$ to cellulase. There were, however, insufficient quantities of sera to assess cross reactivity between the enzymes.

Table 1 details the levels of sensitisation to these workplace allergens, compared to the presence of respiratory and nasal symptoms, and reports Mantel-Haenszel common odds ratio estimates. These data show a significant relation between sensitisation to enzymes (with or without wheat flour) and prevalence of any nasal $\left(\chi^{2}\right.$ value $\left.11.9, \mathrm{p}=0.001\right)$, and work related nasal symptoms ( $\chi^{2}$ value $\left.13.4, \mathrm{p}<0.0001\right)$, compared to non-sensitised individuals. The prevalence of such symptoms was greater in those sensitised to enzymes compared to wheat flour, which in turn was greater than those not sensitised.

\section{DISCUSSION}

The inhalation of cereal allergens has been suggested as a cause of sensitisation and the reporting of respiratory symptoms in bakers. However, the list of potential causative agents has increased to include agents such as flours from other sources, storage mites, and now enzymes of the Aspergillus lineage. In this study, we showed sensitisation to either cellulase, hemicellulase, or xylanase in $6 \%$ of bakery workers studied. Due to insufficient sera, it was not possible to investigate the degree of cross reactivity between these enzymes. Previous work has, however, showed a degree of cross reactivity between xylanase and cellulose, ${ }^{9}$ and as the hemicellulase extract may have had a xylanase component, cross reactivity between these cannot be ruled out. Interestingly however, Quirce and colleagues ${ }^{3}$ reported no cross reactivity between cellulase and $\alpha$-amylase, and in the
Policy implications

- During the health assessment of workers in the baking industry, it would be of use to include an evaluation of sensitisation to cellulase, hemicellulase, and xylanase as well as to $\alpha$-amylase and cereal allergens.

current study two workers with specific IgE to the mixed enzymes showed no detectable specific IgE to fungal $\alpha$ amylase. This suggests that these enzymes should be included in the evaluation of sensitisation in bakers.

The present study suggests a significant relation between sensitisation and prevalence of "any", and "work related" nasal symptoms. Importantly, nasal symptoms were significantly more prevalent in the enzyme sensitised group compared to those sensitised to wheat flour allergens alone. This increased association of nasal symptoms in individuals sensitised to enzymes underlines the importance of evaluating sensitisation to both wheat flour and enzymes used in the baking industry. While limited by sample availability, this study is one of the first to show a relation between clinical symptoms and sensitisation (measured by a positive RAST test) to other allergens within the flour improver mix.

Because this was a cross sectional study in a limited number of samples from small bakeries, it is not possible to comment further on the relation between sensitisation and symptoms suggestive of rhinitis. However, it is plausible to conclude that nasal symptoms may be a consequence of sensitisation relating to the repeated exposure to airborne agents, and in particular enzymes used in this industry. Furthermore, it is reported that rhinitis is a risk factor for asthma, ${ }^{10}$ and it is conceivable that work related nasal symptoms represent early airway responses to allergen, and may identify an "at risk" group with a greater likelihood of developing occupational asthma.

\section{ACKNOWLEDGEMENT}

The authors wish to thank Mr Edward Robinson for help in the analysis of samples and proofreading the manuscript.

\section{Authors' affiliations}

J Elms, D Fishwick, J Walker, A D Curran, Health and Safety Laboratory, Broad Lane, Sheffield S3 7HQ, UK

P Jeffrey, Health and Safety Executive, 375 West George Street, Glasgow G2 4LW, UK

Table 1 Prevalence of sensitisation in symptomatic individuals

\begin{tabular}{|c|c|c|c|c|}
\hline $\begin{array}{l}\text { Sensitisation } \\
\text { status }\end{array}$ & Symptoms & No symptoms & $\begin{array}{l}\text { Odds ratio }(95 \% \mathrm{Cl}) \\
\text { compared to group } 1\end{array}$ & $\begin{array}{l}\text { Odds ratio }(95 \% \mathrm{Cl}) \\
\text { between groups } 2 \text { and } 3\end{array}$ \\
\hline \multicolumn{5}{|c|}{ Any respiratory symptoms } \\
\hline 1 & 65 & 39 & 1.0 & to \\
\hline 2 & 9 & 4 & 1.35 (0.39 to 4.67$)$ & 1.0 \\
\hline 3 & 12 & 6 & $1.2(0.42$ to 3.49$)$ & 0.89 (0.19 to 4.12 ) \\
\hline \multicolumn{5}{|c|}{ Work related respiratory symptoms } \\
\hline 1 & 27 & 77 & 1.0 & to \\
\hline 2 & 2 & 11 & 0.52 (0.11 to 2.49 ) & 1.0 \\
\hline 3 & 5 & 13 & $1.10(0.36$ to 3.37$)$ & $2.16(0.34$ to 13.16$)$ \\
\hline \multicolumn{5}{|c|}{ Any nasal symptoms } \\
\hline 1 & 41 & 63 & 1.0 & to \\
\hline 2 & 6 & 7 & $1.32(0.41$ to 4.20$)$ & 1.0 \\
\hline 3 & 15 & 3 & $7.68(2.09$ to 28.5$)$ & 5.85 (1.12 to 30.3$)$ \\
\hline \multicolumn{5}{|c|}{ Work related nasal symptoms } \\
\hline 1 & 14 & 90 & 1.0 & to \\
\hline 2 & 5 & 8 & 4.01 (1.15 to 14.08$)$ & 1.0 \\
\hline 3 & 9 & 9 & $6.42(2.18$ to 18.87$)$ & $1.6(0.38$ to 6.80$)$ \\
\hline
\end{tabular}

Sensitisation status: $1=$ not sensitised; $2=$ WF only; $3=$ enzyme plus or minus WF. WF, wheat flour. 
M Gibson, Health and Safety Executive, Belford House, 59 Belford Road, Edinburgh EH4 3UE, UK

R Rawbone, P Griffin, Health and Safety Executive, Bootle, Merseyside L2O 3QZ, UK

Correspondence to: Dr J Elms, Health and Safety Laboratory, Broad Lane, Sheffield S3 7HQ, UK; joanne.elms@hsl.gov.uk

Accepted 17 December 2002

\section{REFERENCES}

1 Brisman J, Belin L. Clinical and immunological responses to occupational exposure to $\alpha$-amylase in the baking industry. $\mathrm{Br} J$ Ind Med 1991;48:604-8.

2 Carmona JGB, Picón SJ, Sotillos MG. Occupational asthma in bakeries caused by sensitivity to $\alpha$-amylase. Allergy 1991;46:274-6.

3 Quirce S, Cuevas M, Diez-Gomez M, et al. Respiratory allergy to Aspergillusderived enzymes in bakers' asthma. J Allergy Clin Immunol 1992;90:970-8.
4 Mergot R, Sander I, Raulf-Heimsoth $M$, et al. Baker's asthma due to xylanase and cellulase without sensitisation to alpha-amylase and only weak sensitisation to flour. Int Arch Allergy Immunol 2001;124:502-5.

5 Baur X, Saver W, Weiss W. Baking additives as new allergens in baker's asthma. Respiration 1988;54:70-2.

6 Baur X, Sander I, Posch A, et al. Baker's asthma due to the enzyme xylanase-a new occupational allergen. Clin Exp Allergy 1998;28:1591-3

7 Jeffrey P, Griffin P, Gibson M, et al. Small bakeries-a cross-sectional study of respiratory symptoms, sensitisation and dust exposure. Occup Med 1999;49:237-41.

8 Ceska M, Eriksonn R. Radioimmunosorbent assay of allergens. J Allergy Clin Immunol 1972;49:1-7.

9 Tarvainen K, Kanerva L, Tupasela O, et al. Allergy from cellulase and xylanase enzymes. Clin Exp Allergy 1991;21:609-15.

10 Malo JL, Lemiere C, Desjardins A, et al. Prevalence and intensity of rhinoconjunctivitis in subjects with occupational asthma. Eur Respir J 1997;10:1513-15.

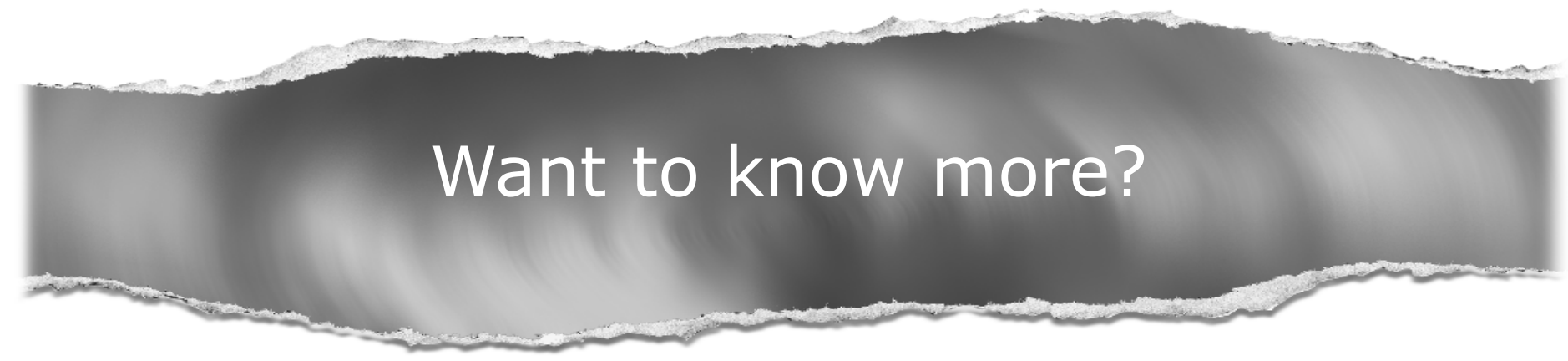

Data supplements

Limited space in printed journals means that interesting data and other material are often edited out of articles; however, limitless cyberspace means that we can include this information online.

Look out for additional tables, references, illustrations.

www.occenvmed.com 